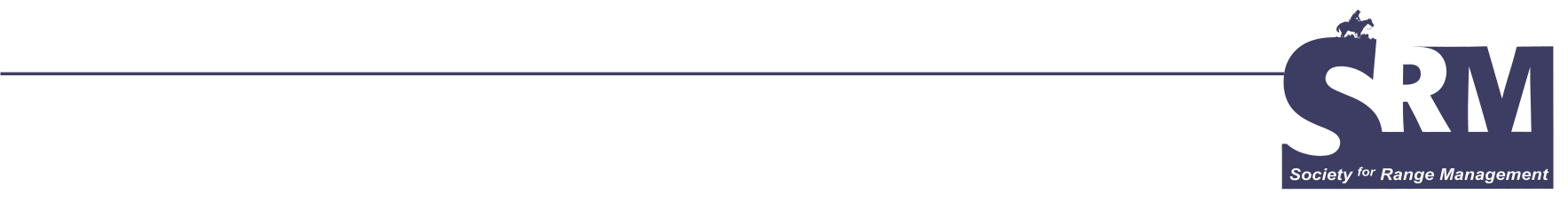

\title{
Back to the Future: Forest Service Rangeland Research and Management
}

\section{By John E. Mitchell, Peter F. Ffolliott, and Marcia Patton-Mallory}

W hy a review of the Forest Service entitled "Back to the Future?" As we shall see, the beginnings of range management within this agency were strongly embedded in the principle of conservation. Rangers were charged with the enormous job of getting control of livestock grazing and improving range conditions. Then, as Char Miller and Ed Marston describe elsewhere in this issue, some aspects of the Forest Service shifted part of their focus during the middle of the last century towards commodity production. We need to bear in mind, however, as the title of the following article so aptly states, that agency leaders and staff officers were "doing the best they could" to carry out the mission given them.

Entering the 21st century, we find the Forest Service has returned to its roots of restoration and conservation within a multiple-use context in new and more vigorous ways. This journey to change has paralleled the shifting values that society has held over the past 100 years, and we should expect the same to happen in the future. Ultimately, values are reflected in laws, and laws, in turn, affect policies. Policies cause actions that give direction to organizations, both public and private. Tom Quigley plainly explains the relationship between values and management in his article in this issue.

\section{The Beginning}

It is difficult to pinpoint the beginning of range management in the colorful history of the United States. During the great western expansions of the mid-19th century, little regard was given to the nation's resources, which seemed to be infinitely abundant. The opportunity always existed to move on to greener pastures after the land had been stripped of its resources. An understanding of the need for conservation in a land of plenty evolved very slowly. In the 1870s, the American Association for the Advancement of Science and the American Forestry Association became sufficiently concerned about the need to preserve and manage forests that they began to promote these ideas to Congress and in various public forums. ${ }^{1}$

The matter of preserving forests was manifested in the General Land Law Revision Act of 1891, which authorized the President to set aside public lands having forests as public reservations called Forest Reserves. The first was the Yellowstone Forest Reserve. By 1900, there were about 40 million acres in Forest Reserves throughout the western states and territories. They were administered by the General Land Office in the Department of the Interior.

Oddly, the 1891 Act did not authorize any funds to be appropriated for managing the Forest Reserves. This caused the General Land Office to issue a regulation that "prohibited the driving, feeding, grazing, pasturing, or herding of cattle, sheep, or other livestock" within any reserve. ${ }^{1}$ The resulting consternation within the livestock industry helped fuel an initiative for Congress to pass the Organic Administration Act of 1897. This Act recognized that the Forest Reserves were established "to improve and protect the forest, to secure favorable conditions of water flow, and to furnish a continuous supply of timber." Passage of the 1897 Organic Act resulted in immediate regulations that allowed cattle grazing in Forest Reserves if it didn't injure forest growth. However, it wasn't until 1900 that sheep grazing was permitted. In every regulation, livestock grazing could only take place if it was compatible with the purposes spelled out in the 1897 Act-forest health, reliable water flows, and an uninterrupted timber supply. 
Although the requirement to manage livestock grazing in a way that promoted forest health and vitality was clearly stated, no body of knowledge existed for doing so. Consequently, those charged with administering the Forest Reserves had to learn how to do so. The need for range research had been identified.

The Transfer Act of 1905 transferred the administration of the Forest Reserves from the Department of Interior to the Department of Agriculture. Thus, the Forest Service was born, and the National Forests were created. It became the agency's responsibility to figure out how to manage livestock grazing lands under their authority.

Grazing activities remained largely uncontrolled and mostly unregulated immediately after the transfer of the Forest Reserves to the Department of Agriculture in 1905. Albert Potter, the first Chief of Grazing of the Forest Service, developed a grazing-use book that reflected agency grazing policies endorsed by President Roosevelt. These included giving preference to small, local livestock operators and requiring them to have deeded, commensurate grazing land that could be used in conjunction with their Forest grazing. Most sheep operators did not have commensurate property, and their elimination from Forest grazing allowed for a large reduction in stocking on National Forests. ${ }^{2}$

Attempting to remedy this problem and contain the level of grazing, the Forest Service announced in 1906 that fees would be imposed on ranchers for livestock grazing on National Forest lands. These fees were set at 25 to 36 cents per head of cattle and horses with a lower rate for sheep and goats. ${ }^{1}$ Forest rangers also controlled grazing by establishing dates for entering and leaving specified rangelands. Grazing revenues exceeded those from timber harvesting every year between 1905 and 1910 and periodically until 1920.

The Office of Grazing Studies was established in 1910 with responsibilities for reconnaissance, administration, and initiation of needed studies on the effects of livestock grazing on the National Forests. James T. Jardine, known for his early research in range inventory methods, was its first head. When Jardine left the Forest Service in 1920, W. Ridgely Chapline replaced him. Six years later, the Office of Grazing Studies relocated within the Forest Service to the Research Branch as the Division of Range Research. "Chappie," as he was called by his friends, stayed on as Chief of the Division for 25 more years. ${ }^{2}$

Livestock grazing increased dramatically on public rangelands with the entry of the United States into World War I. Federal agencies, especially the Forest Service, were under great pressure to help increase the supply of red meat, wool, and leather. ${ }^{2}$ Grazing was even allowed in Yellowstone and Glacier National Parks. ${ }^{1}$ The increased grazing on National Forests, administered under temporary permits, was encouraged by the Chief in a 1917 letter to the field. After the war, the job of removing excess livestock numbers was long and laborious. A common statement during the 1930s and 1940s was, "There's nothing so permanent as a temporary grazing permit." (B. Hurst, personal communication, April 2, 2005).

\section{SRM Chapline Awards}

In 1986, Chappie Chapline established an endowment within the Society for Range Management that the Society translated into 2 awards: the W. R. Chapline Research Award and the W. R. Chapline Land Stewardship Award. Only the Frederic G. Renner Award is considered more prestigious by SRM than the Chapline Awards. Fittingly, the first Chapline Research Award was presented in 1987 to a Forest Service rangeland scientist, Henry A. Pearson, for his work on integrated forest and rangeland management strategies in the South. The first Chapline Land Stewardship Award went to John L. "Chip" Merrill. Unfortunately, Chapline passed away less than 2 months before these first awards were given. ${ }^{3}$

It took years to recover from this action. Fortunately, the Forest Service didn't repeat this mistake in policy during World War II, even though demands for the same rangeland products were just as high.

\section{Early Forest Service Research}

An article in this issue by Susan Olberding and her coauthors depicts events leading to the first range research projects that took place in the Southwest, including the establishment of research stations in Arizona at Fort Valley and Santa Rita, and in New Mexico at Jornada. Here, we will examine other pioneering work promoting management tools to sustain livestock use of rangelands consistent with the purpose of the National Forests.

Perhaps the most imminent range researcher in these early years was Arthur W. Sampson, known to his students and colleagues as "Sammy" (Fig. 1). After receiving an MS degree at the University of Nebraska in 1907, where he studied under Frederic Clements, Sampson accepted a position with the Forest Service as a plant ecologist. His first assignment was to study the effects of overgrazing in the Blue Mountain Forest Reserve, located in northeastern Oregon. His ability to observe and understand effects of disturbance on plant communities led to numerous publications, a seminal one published in $1919 .{ }^{4}$

Between 1912 and 1922, Sampson served as the first Director of the Great Basin Experiment Station on the Wasatch Plateau near Ephraim, Utah, which was established to carry out range research on degraded and eroding high mountain watersheds. ${ }^{5} \mathrm{He}$ was one of the first to report on the effects of grazing on aspen reproduction. W. R. Chapline worked with Sampson at the Great Basin Station before becoming Chief of the Office of Grazing Studies.

After receiving a $\mathrm{PhD}$ in 1917, Dr Sampson joined the faculty at the University of California, Berkeley. His research on succession and plant indicators, as well as his textbooks on range management, greatly enhanced rangeland management throughout the West during the early years when 


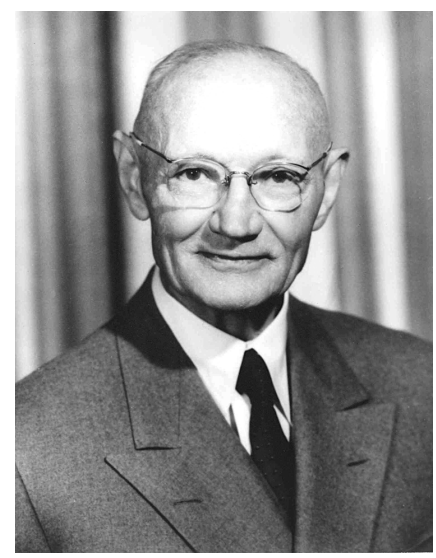

Figure 1. Arthur W. Sampson, eminent Forest Service ecologist, and later, Professor at the University of California. Dr Sampson published numerous papers on the distribution and function of various rangeland plants, plant succession, grazing effects, and range improvement procedures. A summary of his life, written by 10 distinguished rangeland scientists, is published in the November 1967 (Vol. 20, No. 6) issue of the Journal of Range Management.
Forest Service Rangers were trying to administer livestock grazing permits. ${ }^{6}$ These early studies by Jardine, Sampson, and Chapline provided rangers with 4 basic principles to aid them in this task: proper kind of livestock, proper number of livestock, correct grazing season, and proper distribution of livestock. ${ }^{7}$

Another scientist of Dr Sampson's caliber carried on his work at the Great Basin Station 30 years later. Lincoln "Linc" Ellison was a brilliant ecologist who conducted pioneering research on grazing effects on montane rangeland plant communities. His classic papers on the character of subalpine vegetation on the Wasatch Plateau ${ }^{8}$ and on how grazing influences plant succession ${ }^{9}$ culminated a distinguished career (Fig. 2). Perhaps Dr Ellison's most notable contribution to rangeland management was manifested in a publication on condition and trend that is still valid today. ${ }^{10}$ Trend in range condition must be considered to be downward when the soil is eroding, regardless of the trend of the associated vegetation. This insight caused the Forest Service to consider range condition equally on the basis of the soil and vegetation components. Sadly, Linc was killed in an avalanche in 1958 while at the height of his career.

It is interesting to note that the Soil Conservation Service (SCS), which employed many more soil scientists than the Forest Service, did not consider soil erosion equally with species composition when describing range trend during this period. A logical reason exists for such an apparent paradox, however: The SCS is responsible for helping private ranchers manage their own lands, and most privately owned rangelands in the West are found at lower elevations below the National Forests where terrain is gentler and soils less erosive. ${ }^{11}$

A. Perry Plummer assumed leadership of the Great Basin Station (later called the Great Basin Experimental Range), following Linc Ellison's tenure. During the mid-20th century, work continued to focus on restoration of degraded rangelands. ${ }^{13}$ Dr Plummer's work, in great part, provided the impetus for establishing the Shrub Sciences Laboratory in Provo, Utah. ${ }^{14}$ During the past 30 years, the Shrub Sciences Laboratory has excelled in research on seed and seedbed ecology, genetics, population biology, and plant taxonomy. ${ }^{15}$

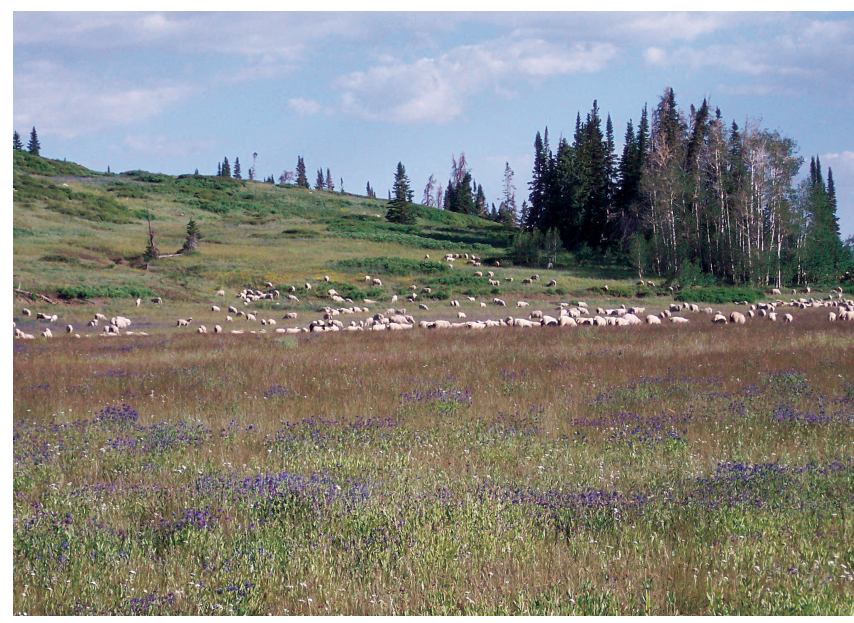

Figure 2. A recent picture of the Wasatch Plateau. Between 1880 and 1905 , overgrazing by sheep and cattle was so pervasive that the "Wasatch Range, from Thistle to Salina, was a vast dust bed, grazed, trampled and burned to the upmost."12 The situation was so bad that serious flooding, unheard of before, occurred in Ephraim Canyon and other canyons almost every other year. Forest Service photo courtesy of C. Johnson, R-4.

In 1922, the Forest Service took over the range research program at the US Sheep Experiment Station near Dubois, Idaho. The Station had been withdrawn from the public domain in 1915 by President Wilson and assigned to the Bureau of Animal Industry (later to become the Agricultural Research Service) to provide a place to conduct research on sheep breeding, grazing management, and reseeding. The Forest Service, under a plan by C. L. Forsling, Director of the Great Basin Experiment Station (precursor to the Intermountain Forest and Range Experiment Station), laid out a series of sheep studies to assess proper use and season of use, carrying capacity and range forage requirements, grazing systems to promote rangeland health, range improvements (including burning), and sheep management procedures. Among the Forest Service scientists who conducted research at the US Sheep Station were George Pickford, Joe Pechanec, Jim Blaisdell, Walt Mueggler, Bill Laycock, Henry Wright, and Roy Harniss. In 1972, the range research at the Sheep Experiment Station was transferred from the Forest Service to the Agricultural Research Service, which had conducted the sheep breeding and other animal-related studies since the Station was established. ${ }^{16}$

Meanwhile, as the importance and use of National Forest resources continued to increase, the Forest Service proposed the creation of a nationwide research program within the agency. This recommendation, along with those of others, led to the passage of the McSweeney-McNary Act of 1928 . This milestone Act, which afforded research a "recognized separation" from National Forest administration, authorized the Forest Service to establish additional experiment stations and increased rangeland research activities. Specifically, it provided for the establishment of a network of 12 regional experiment stations that would form the "backbone" of Forest research. ${ }^{17}$ 
In addition to locations throughout the Southwest, Intermountain, and Rocky Mountain regions, Forest Service range experiment stations were established in the West Coast states. The San Dimas Experimental Forest, located in the foothills of the San Gabriel Mountains of southern California near Los Angeles, was established in 1933 and formally dedicated as a Forest Service research site in 1935. Research has been and continues to be oriented toward studying the effects of air pollution from Los Angeles and the frequent occurrence of fire on the inhabiting chaparral vegetation. The San Joaquin Experimental Range on the western slopes of the central Sierra Nevada Mountains of California was established in 1934 to ascertain the possibilities of sustainable livestock (cattle) husbandry in a transitional oak shrub community. A diversity of range improvement studies involving applications of fertilizers and prescribed burning treatments have also been carried out on this 2,000-acre foothills ecosystem.

The Starkey Experimental Forest and Range was carved out of the Whitman National Forest near La Grande, Oregon, in 1940. Originally designated as a facility to study grazing responses to native and introduced forage species, Starkey undertook a major change in mission when future Forest Service Chief Jack Ward Thomas initiated a large study evaluating interactions among elk, deer, cattle, recreation, and forest management. This study continues today. Among the Forest Service scientists who have conducted research on the Starkey are Richard Driscoll, Jon Skovlin, Gerald Strickler, Jack Ward Thomas, Larry Bryant, Tom Quigley, and Marty Vavra. ${ }^{18}$

Senate Document No. 199, The Western Range, was an assessment of US rangelands based, in part, on Forest Service research findings and administrative records. ${ }^{19}$ This classic report, published in 1936, reached a number of conclusions, among them: 1) that $99 \%$ of the 728 million acres of rangeland in the continental United States was "available for grazing"; 2) during the preceding 30 years, $95 \%$ of rangelands in the public domain had declined in condition whereas only $2 \%$ had improved; 3 ) the primary cause of rangeland depletion was excessive grazing use, which would have to be dramatically curtailed if trends were to be turned around; and 4) at least 589 million acres of rangeland was eroding "more or less seriously." The apparent incongruity between such an extensive level of downward trend and the belief that essentially all rangeland is available for livestock grazing was obviously consistent with values still prevalent in the 1930s.

Two illustrations in The Western Range clearly portrayed the early conservation history on National Forest lands (Fig. 3). The 1st showed rangelands on National Forests to be less depleted than rangelands on public domain, tribal lands, state and county lands, and private ranches. The 2nd shows National Forest rangelands to be primarily in an upward trend whereas those on other lands were becoming more depleted. The authors surmised, however, that rangelands on the National Forests at the time they were set aside 30 years a

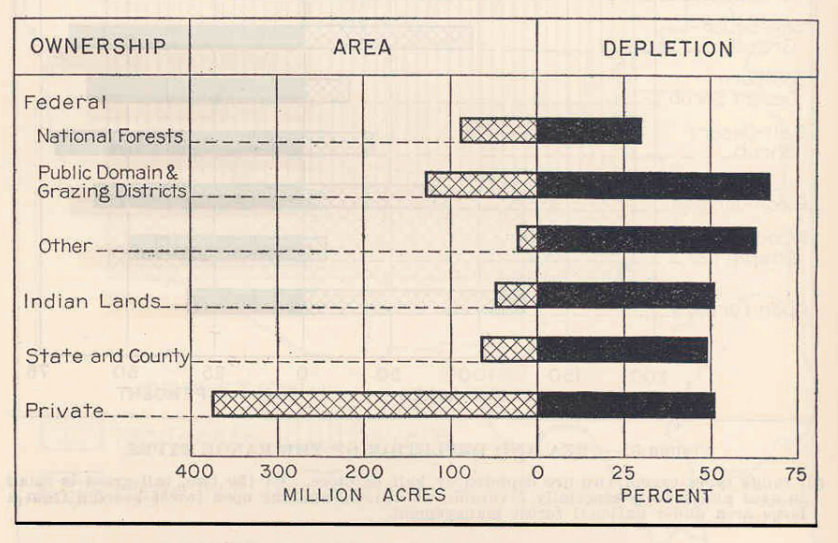

b

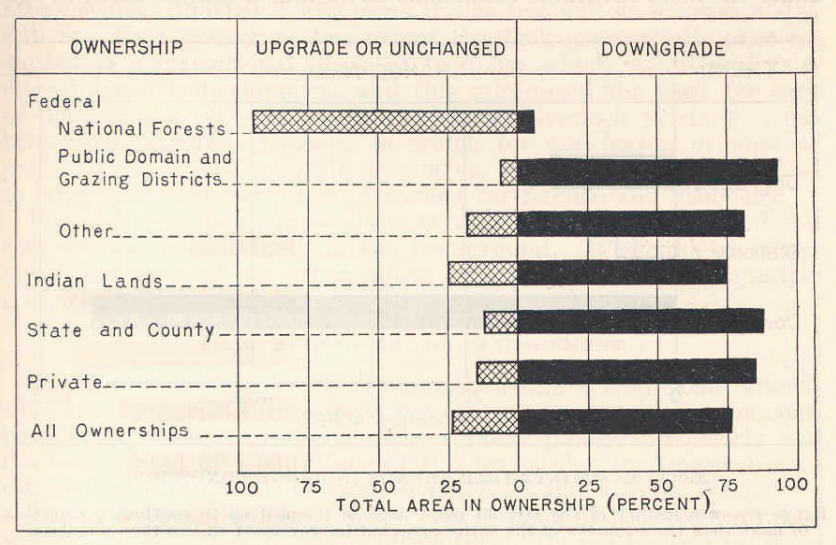

Figure 3. The estimated area of rangeland and percentage of depletion for 6 land ownership categories in 1935 (top), and the trend in depletion for the same 6 categories during the preceding 30 years (bottom). ${ }^{19}$

earlier had probably been in even worse condition than lands on the public domain "because of the comparative abundance of water on the National Forests and of the general shortage of summer range." ${ }^{19}$

Speaking of water, with many major rivers in the West originating on National Forests, issues surrounding stream flow, watershed protection, and effects of vegetation cover on runoff and erosion were of high importance to Forest Service leaders and researchers. In 1910, Henry Graves, who had just been selected as Chief after the firing of Gifford Pinchot by President Taft, established the Wagon Wheel Gap Experimental Watershed on the Rio Grande National Forest. Although studies there were short-lived, they opened the way for a rich history of watershed research within the agency. Experimental watersheds at Beaver Creek, Arizona; the Black Hills, South Dakota; Fraser, Colorado; San Dimas, California; Manitou, Colorado; and elsewhere were established before and during the drought of the 1950s. Today, Forest Service research has shifted its emphasis away from rangeland-dominated watersheds that assess water yield in relation to management practices, although scientific 


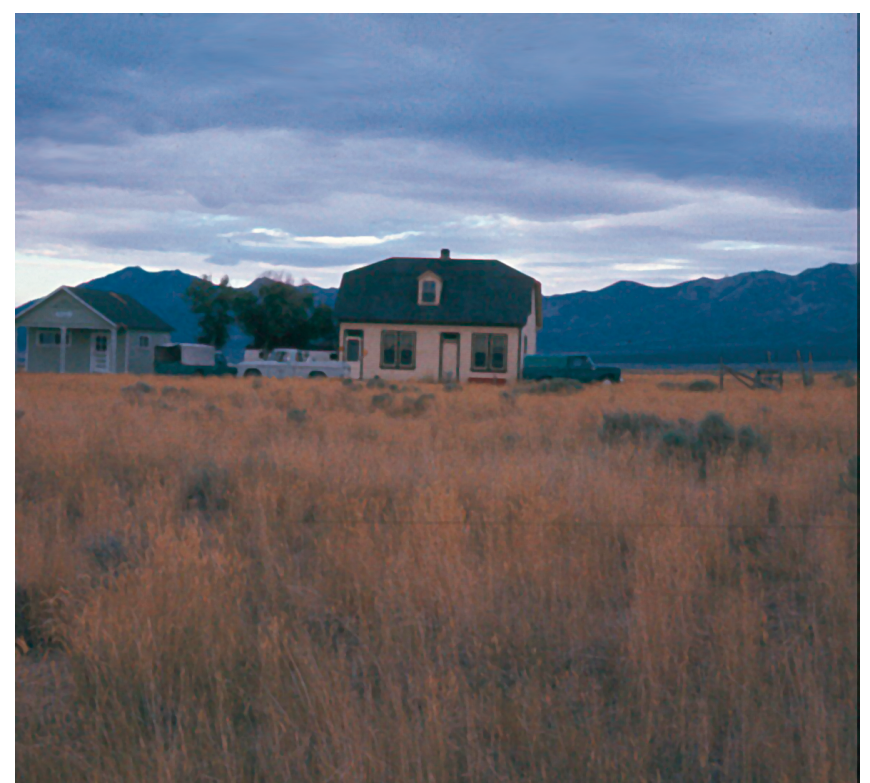

Figure 4. Benmore Experimental Range near Vernon, Utah, 1964. Numerous studies took place here during the mid-20th century on interactions between livestock grazing and crested wheatgrass seedings. Photo courtesy of John Mitchell.

advances are still needed to understand basic infiltration and runoff processes and to apply fine-scale data for reaching useful watershed-level estimates of these processes. ${ }^{20}$

\section{Managing for Livestock Production}

By mid-20th century, research interests had expanded from only protection and restoration to include goals related to commodity outputs. After all, 99\% of the nation's rangelands had earlier been deemed suitable for livestock production. ${ }^{19}$ The range management textbook published in 1943 by L. A. Stoddart and Arthur D. Smith defined range management as "the science and art of planning and directing range use as to obtain the maximum livestock production consistent with conservation of the range resources" (italics added). ${ }^{21}$ Their second edition, published 12 years later, well after wartime demands for meat and leather had subsided, contained the same definition.

Forest Service range research, like the timber research program, began to place increasing emphasis upon commodity production - in this case, the amount and quality of forage available for livestock. The Desert Experimental Range, located about 50 miles west of Milford, Utah, was established in 1933 to show how the salt desert shrub zone could be managed to enhance sheep production and how different grazing strategies affected the vegetation. ${ }^{22}$

One way of increasing livestock production is to control losses from poisonous plants and annuals that produce forage for only a short period of time. ${ }^{23,24}$ During the mid-20th century, large areas of public domain in the Great Basin were planted with an introduced species, crested wheatgrass, for the control of halogeton and, to a lesser extent, cheatgrass. Crested wheatgrass was seeded even more extensively throughout the West, including on National Forest land, to improve production on rangelands degraded by drought and prior overgrazing.

The Benmore Experimental Range was established near Vernon, Utah, in the mid-1930s to study the ecology and management of crested wheatgrass in relation to livestock production systems (Fig. 4). ${ }^{25}$ Until 1954 when the Forest Service acquired it, Benmore was administered by several different agencies, primarily the SCS. During this period, crested wheatgrass was considered by some to be "the golden grass of the West." Benmore closed in 1984 just as increasing emphasis was being placed on using native species in rangeland rehabilitation instead of exotics. Slowly, the concept of rangeland "improvement" was being replaced by that of "restoration."

Forest Service research and management interest in livestock production on National Forest system lands significantly expanded in 1954 when Land Utilization Project (LUP) lands were transferred to the agency from the SCS. These lands had been earlier purchased under provisions of the Bankhead-Jones Farm Tenant Act of 1937 by the Department of Agriculture, primarily as abandoned dust-bowl farms. Congress attempted to address 2 dilemmas when it passed this Act-aiding farm ownership (and sustaining rural communities) and correcting ecological damage caused by farming submarginal lands. The USDA officials believed a controlled grazing program on the LUP lands would help the remaining farmers earn a living adequate for them to stay on the land.

By the time the Forest Service took over the LUP lands, a great deal of effort had been expended by the SCS in seeding abandoned farms to grass, establishing grazing associations, emphasizing proper grazing management, and administering grazing permits. After being transferred to the Forest Service, the LUP lands were formally designated as National Grasslands. Most of these 20 grasslands, now totaling nearly 4 million acres in aggregated area, are located within the Rocky Mountain Region. ${ }^{26}$

The Forest Service has long managed its National Grasslands for multiple uses, including livestock grazing, oil and gas exploration, wildlife habitat, and recreation. Until 1974, their management mostly focused on forage production for livestock, partly because of language in the legislation that created them. Ezra Taft Benson, Secretary of Agriculture under President Eisenhower, insisted that the LUP lands be used for "promotion and demonstration of the benefits of sound grassland management." Language similar to this subsequently made its way into the Forest Service manual (S. Tixier and B. Hurst, personal communication, April 3, 2005).

Congress formally integrated the National Grasslands into the National Forest system when it passed the Forest and Rangeland Renewable Resource Planning Act of 1974 (RPA). As a result, the National Grasslands not only fell under the provisions of the Bankhead-Jones Act but also other acts applicable to all National Forests. During the past 30 years, increasing emphasis has been placed on managing National Grasslands 


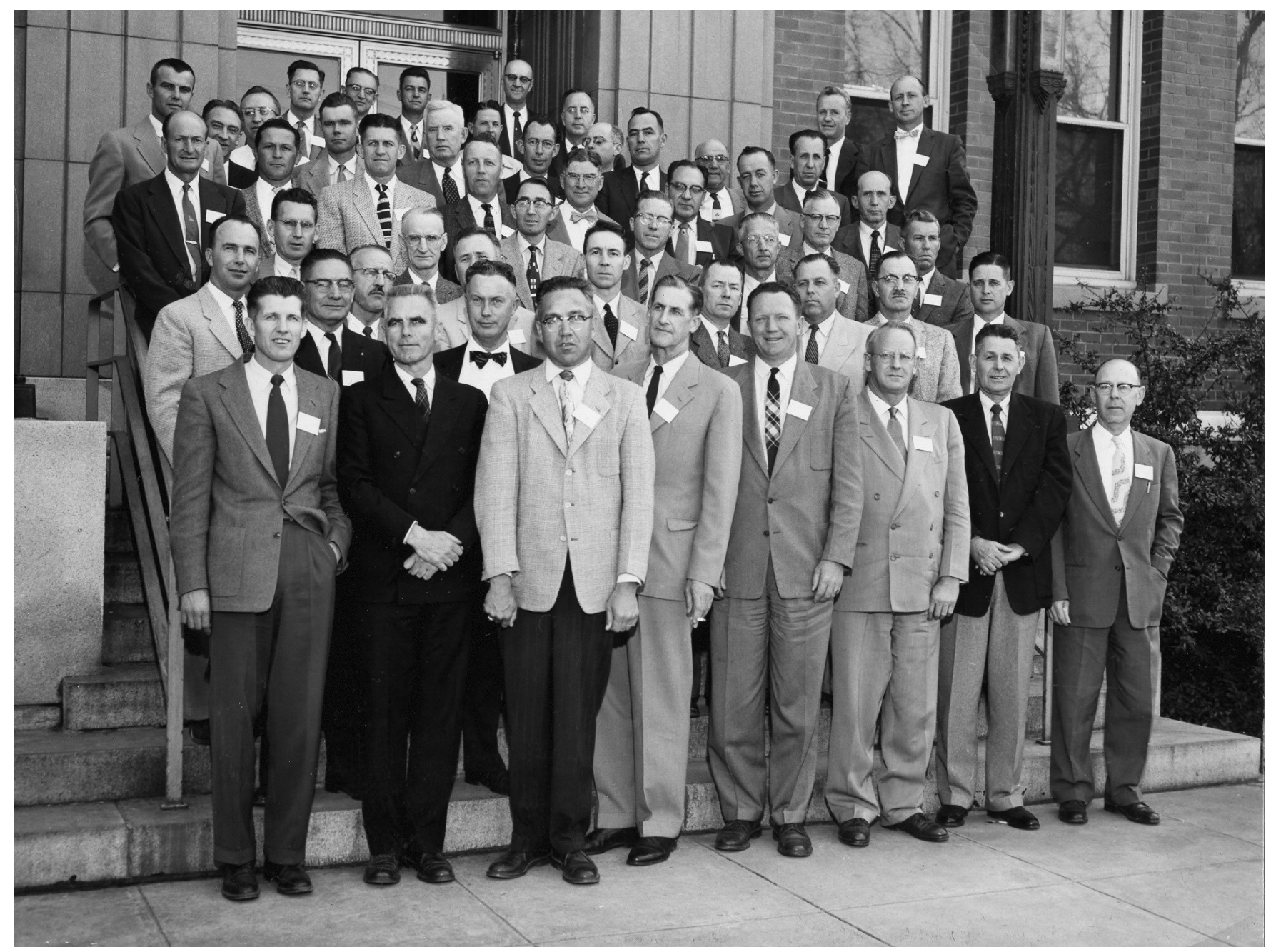

Who's Who-Leaders in Forest Service Rangeland Science and Management

This photograph was taken at a livestock-big game range analysis conference, held in Ogden, Utah, from April 9, 1956, to April 13, 1956. The photograph was provided by Nancy Shaw, Botanist with the Rocky Mountain Research Station, from the estate of Joe Pechanec. The original is presently framed in the Office of the Director of Range Management, WO.'

The attendees in the photograph are listed below:

\section{First row (from left):}

- Jim Blaisdell, INT., ii Range scientist who retired as an Assistant Director. Senior author of a far-reaching article on future directions of range research. ${ }^{36}$

- Lincoln Ellison, INT., ii Pioneering researcher in ecology and management of montane rangelands.

- R. K. Blacker, R-2.' Later was Supervisor on the San Juan National Forest.

- Fred W. Johnson, R-1.,ii Director of Range Management.

- A. L. "Gus" Hormay, CAL., ii Father of the rest-rotation grazing system. ${ }^{37}$

- Selar Hutchings, INTi, i Expert on forage inventory and monitoring.

- Charles A. "Chick" Joy WO., ii Division Chief, Range Management.

- David F. Costello, PNW., ii Director, Division of Range Research.

\section{Second Row:}

- C. E. McDuff, R-3. Director of Range and Wildlife.

- Ken W. Parker, WO. ii Director, Range Management and Wildlife Habitat Research. Developer of the 3-step method for condition and trend analysis.

- Robert W. Harris, PNW. "i Assistant Director. Later, he was PNW' Director and Associate Deputy Chief for Research, Forest Service.

- Elbert H. "Bert" Reid, RM., i Assistant Director. Conducted pioneering work on the succession of green needlegrass and other species in the Blue Mountains of Oregon. Editor of the Journal of Range Management from 1969 to 1977.

- L. W. Hornkohl, R-9.' Range Conservationist.

- Walter O. Hanson, R-6.' Retired as Director of Wildlife Management, Forest Service. 
Who's Who-Leaders in Forest Service Rangeland Science and Management (continued)

\section{Third Row:}

- Frank Smith, R-2. Supervisor, Rio Grande National Forest. Later was R-3 Director of Range Management and Director of Range Management, Forest Service.

- Clyde Doran, R-2., ii Retired as Supervisor of Coronado National Forest.

- Avon Denham, R-6., ii Retired as Director of Range Management, Region 6.

- John Clouston, R-6., ii Range Staff. Served as the Executive Secretary of SRM between 1957 and 1968 while the Society's headquarters was in Portland, Oregon. In 1968, Francis Colbert was appointed as a full-time Executive Secretary and the SRM headquarters was moved to Denver, Colorado.

- I. Pat Murray, R-4, ii Ranger. Later, was the Supervisor on National Forests in 3 regions-Caribbean (Puerto Rico, R-8), Shoshone (R-2), and Cibola (R-3). During WWII, Murray was an aide to General Patton, and some say he brought the General's character with him to the Forest Service!

- Barry Park, R-1., ii

- Wayne West, R-6., ii Range staff officer.

- Odell Julander, INT., ii Specialized in rangeland-wildlife interactions, particularly with deer and pocket gophers.

- Ralph Hill, R-2. Assistant Director for Wildlife.

- Frank Curtiss, R-1.' Retired as Director, Division of Range Management, R-4.

- E. J. Woolfolk, CAL., ii Conducted research on rangeland fertilization in California grasslands.

\section{Fourth Row:}

- Lowell G. Woods, R-4.' Retired as R-3 Director of Watershed.

- George Proctor, R-3. Supervisor of the Carson National Forest. Like Woods, he retired as R-3 Director of Watersheds. A real character!

- Lloyd L. Bernhard, R-5.' Range staff officer.

- I. H. "Hap" Johnson, R-4.' Range specialist and an exceptional ecologist.

- Lloyd Swift, WO.' Director, Division of Wildlife Management.

- Reginald M. DeNio, R-5., ii Director of Wildlife. Later, "Reg" became Director of Range, WO.

- Basil Crane, R-2. ii Earlier, had studied condition and trend of meadows in the Sierra Nevada's. Crane retired as R-2 Deputy Regional Forester.

- D. I. Rasmussen, R-4. Director of Wildlife. Started the Dept. of Wildlife at Utah State University in mid-1930s at the same time Dr L. Stoddart established the Department of Range Management. Retired as Director of Wildlife Management, WO.

\section{Fifth Row:}

- S. L. "Buck" Cuskelly, R-4. Supervisor, Fish Lake National Forest. Later was Director of Watershed Management, R-4. Died at relatively early age.

- Merton J. Reed, WO., ii Division of Range Research. Earlier, had worked in rangeland inventory and analysis in California.

- Floyd Iverson, R-4, iii Regional Forester. Strong proponent of multiple use management.

- Everett R. Doman, WO. i, iiv Director of Wildlife Management, WO. Pioneering wildlife biologist and rangeland conservationist in R-4. Director of Range and Wildlife, R-5.

- Jack H. Bohning, RM. iii, iv Range ecologist. SRM President in 1982. Flew fighters and dive bombers in the Pacific during WWII and retired from the Marine Corps Reserve as a Colonel. Jack served on the R-3 range staff where he wrote the Regional Range Analysis Handbook.

- Ted Fearnow, R-7. Director, Range, Wildlife and Watershed.

- W. W. "Wally" Dresskell, R-1.' Director of Range and Wildlife. Later joined Department of the Interior.

- Allan G. Watkins, R-3,i, ii Staff officer, Division of Range Management.

- R. E. Courtney, R-3. Retired as Supervisor of the Tonto National Forest.

- C. J. Olson, R-4., ii Retired as R-4 Regional Forester.

- R. E. Latimore, R-4.' Retired as R-5 Director of Range and Wildlife.

- Edward P. Cliff, WO., ii Chief of the Forest Service from 1962 to 1972. Promoted multiple use management and collaboration between grazing and timber interests. Foresaw the importance of recreation on National Forests. Earlier, he was Chief of Range Management in R-4. ${ }^{38}$

- H. D. Miller, R-8.'

- William D. Hurst, WO, ii, iv Pioneering line and staff officer in R-3 and R-4. R-3 Regional Forester from 1966 to 1976. SRM President in 1970. Both his father, William M. Hurst, and grandfather, William R. Hurst, who was hired into the Forest Service in 1905 by Gifford Pinchot, wore Forest Service green. At the time of this picture, Bill was Assistant Chief, Division of Range Management, where he shared an office with Ken Parker.

- Fred P. Cronemiller, R-5.' Ecologist. Later was Chief, Division of Wildlife, R-5.

- Mont E. Lewis, R-4. ii Highly respected range staff officer. Lewis was also an exceptional botanist, specializing in the genus Carex. He may hold the record as a Forest Service volunteer because every day for a quarter century after retiring, Mont either worked in the INT herbarium or was in the field collecting plants.

- Joseph F. Pechanec, WO., ii Director, Division of Range Research. Later, was Director, INT. Conducted pioneering research in the 1940s on sagebrush ecology and management. First President of SRM. First recipient of SRM Outstanding Achievement Award.

- Herman F. Olson, R-9.' Range Wildlife staff.

WO = Washington Office (Nat'l HQ), INT = Intermountain Station, PNW = Pacific Northwest Station, CAL = California Station (now Pacific Southwest), RM = Rocky Mountain Station, R-1 = Northern Region, R-2 = Rocky Mountain Region, R-3 = Southwestern Region, R-4 = Intermountain Region, R-5 = Pacific Southwest Region, R-6 = Pacific Northwest Region, R-7 = Eastern Region, R-8 = Southern Region, R-9= Great Lakes Region. Note: In 1965, R-7 was abolished and most of its forests were assigned to R-9. R-9 was renamed the Eastern Region.

ii Charter member of SRM.

iii Joined SRM in 1948, but not a charter member.

iv Attended 2005 SRM Annual Meeting in Fort Worth. 
for wildlife habitat, recreation, and environmental concerns. ${ }^{26}$

The RPA goes well beyond its connection with National Grasslands. It requires the Forest Service to prepare a renewable resource assessment of "the forest and rangeland situation" every 10 years. The 1 st assessment was submitted to Congress in March 1976, and a 2nd, more comprehensive, document was published in January 1980. These assessments projected that demand for grazed forage would increase by 40\% during the 50-year period between 1980 and 2030from 213 million animal unit months (AUM) to approximately 300 million AUM. The principal factors driving such a rapid escalation in demand were forecasts for an increasing human population and simultaneous increased per capita consumption of red meat. ${ }^{27}$

An expected $40 \%$ increase in demand for rangeland forage influenced the Forest Service to look for ways to augment existing forage supplies without causing adverse effects on other uses. For example, the Northern and Intermountain Regions set planning goals that could only be met by expanding the grazing use of transitory ranges. Transitory ranges are forested areas that produce forage for a few years following timber harvest until tree regeneration establishes an overstory and shades out the understory vegetation. Transitory range can only be used by livestock under conditions that do not harm the tree regeneration, so managers and researchers quickened their programs and studies aimed at increasing grazing on these areas. Elsewhere in this issue, Tom Quigley describes the Oregon Range Evaluation Project, designed to study grazing strategies for producing more red meat.

Even though the Forest Service had placed increased emphasis on managing for livestock production, the slow trend in the condition of rangelands on National Forests and Grasslands continued to improve. ${ }^{28}$ By the latter part of the 20th century, invasive species were becoming a rising problem, keystone species like quaking aspen were in decline, fragmentation and biodiversity were new issues to be dealt with, and management of riparian areas had become a high priority.

\section{Sustainable Resource Management}

"Back to the Future" began with the environmental movement of the 1970s. The Wilderness Act became law in 1964. ${ }^{29}$ Then, commencing with the National Environmental Policy Act of 1969 (which actually passed Congress in January 1970), no fewer than a dozen major environmental laws having a direct or indirect effect on the management of our National Forests were enacted during the following decade. They included the Wild Horse and Burro Protections Act, the Endangered Species Act of 1973, the RPA, the Federal Noxious Weed Act of 1974, the Federal Land Policy and Management Act of 1976, the National Forest Management Act of 1976, the Soil and Water Resources Conservation Act of 1977, the Forest and Rangeland Renewable Resources Research Act of 1978, and the Public Rangelands Improvement Act of 1978 (which established the formula for federal grazing fees still used today).
When the 3rd edition of Range Management was published in 1975, the definition of range management had changed to "the science and art of optimizing the returns from rangelands in those combinations most desired by and suitable to society through the manipulation of range ecosystems." 30 This broader perspective of rangeland science and management imposed significantly larger workloads on the Forest Service and other land management agencies, and employees with different skills became needed.

Until the Federal Advisory Committee Act, passed in 1972, National Forest officers relied on advisory boards, including grazing advisory boards, for providing citizen input into the way the agency managed National Forests. In particular, the multiple use advisory boards included representatives from recreation interests, wildlife advocates, and nature lovers - in addition to ranchers and timber concerns (B. Hurst, personal communication, April 2, 2005). However, the National Forest Management Act of 1976, for the 1st time, allowed anyone to participate formally in the planning process on National Forests, and the tide of society was slowly turning away from the anthropocentric perspective that primarily valued livestock production on public lands to a more ecocentric viewpoint valuing ecosystem services like biodiversity, clean air and water, aesthetic views, and recreational opportunities. The overlapping domains of rangeland research and management were rapidly becoming more complex!

Later, the 1989 RPA Assessment came up with revised supply and demand projections for grazed forage in the United States during the 50-year period ending in 2040. It concluded that per capita demand for beef was leveling off at the same time advances in technology were expected to increase the production of red meat on private rangelands. As a result, the report deduced that additional forage demands could be supplied from the private sector, thus relieving the federal agencies of the expectation of having to plan on producing more forage from public rangelands. ${ }^{27}$

A big change in the way the Forest Service does business was foretold in recommendations contained in a 1990 report by the National Academy of Sciences (NAS) about future needs for forest research. Partly as a consequence of the NAS report, the Forest Service, under Chief F. Dale Robertson, established a fresh approach for improving ecosystem management and research that increased the ties among the social, biological, and management sciences as they related to the management of National Forests. ${ }^{31}$ The main premise behind this new direction, called "New Perspectives for Managing the National Forest System," or simply "New Perspectives," was to sustain the values and uses provided by ecosystems by emphasizing ecological principles. Of course, most tenets of range management, established and practiced since the beginning of the agency, are based on sound ecological principles.

In 1992, Chief Robertson made known a new management philosophy for managing National Forests, called "Ecosystem Management." The ideas behind "New 
Perspectives" had paved the way for "Ecosystem Management." Behind its overall goal of maintaining ecosystem integrity, the Chief defined 4 specific purposes of ecosystem management: 1) take care of the land by protecting or restoring the integrity of its soils, waters, biodiversity, and ecological processes [by now this should sound familiar!]; 2) take care of the people and their cultural diversity by meeting the basic needs of people and communities who depend on the land; 3) strive for a balance between these first two concepts; and 4) use resources wisely and efficiently to improve economic prosperity. Accomplishing this would necessitate organizational change, cooperation among agencies, better monitoring, and the use of adaptive management. ${ }^{32}$

The strategic objective of ecosystem management, to find the middle ground between protecting the environmental and providing the natural resources needed by an everincreasing population to maintain its well-being, has transformed to a new concept-sustainable management.

The concept of sustainable management involves considering ecological, economic, and social criteria for assessing the association between maintaining healthy, productive rangelands and the well-being of communities and economies at various scales. ${ }^{33}$ The implementation of sustainable management impacts both research and management. Reaching its goals involves a recursive process whereby agencies develop a national strategy (and local plans) for how they will meet the goals of sustainable management, then monitor and assess how well they are meeting the strategy (or goals), then modify the way various programs are organized and administered. Feedback from assessments are then used to confirm or modify the original strategy (or plans), and the process starts over. ${ }^{34}$

At a local level, goals are expressed in resource management plans, required of every National Forest by the National Forest Management Act of 1976. These "forest plans" must be revised at least once every 15 years. As an example of how relevant forest plans are to rangeland monitoring and management, the agency reports how well grazing allotments are being managed in relation to meeting, moving toward, or neither meeting nor moving toward rangeland-related components of forest plans - not on rangeland condition and trend. ${ }^{27}$

Nationally, the Forest Service helped conceive and plays an active role in the Sustainable Rangelands Roundtable, a grassroots group of agencies, nongovernmental organizations (NGOs), academicians, and other rangeland stakeholders organized to promote the ecological, economic, and social sustainability of rangelands through the development and widespread use of criteria and indicators for rangeland assessments and by providing a forum for dialogue on issues pertaining to rangeland sustainable management. ${ }^{35}$

At all levels of rangeland administration, it is generally not the ecological questions that are most difficult to settle; after all, we've been learning how to manage rangeland ecosystems for 100 years. Rather, the socioeconomic and legal-institutional conditions pose the biggest challenges. As
Ellie Towns observes earlier in this issue, it's the interface of humans and societies with ecosystems that makes managing so much fun! Researchers also face a tough job of showing how various indicators and their interactions actually relate to a desired mix of environmental and economic conditions and human well-being.

So, all things considered, today's men and women entering the suite of professions needed to help the Forest Service provide the ecosystem services (forage; water; protection from floods, erosion, and drought; biodiversity; recreational opportunities; a sense of place, etc) desired by society in the 21st century face an exciting but demanding future. They have technological tools unheard of by those in previous generations, tools such as the Internet, powerful computers and associated software, the global positioning system, and detailed satellite imagery. On the other hand, the challenges are just as great, that is, caring for our National Forests and Grasslands to meet the needs of the present and future generations in an increasingly complex and uncertain world.

\section{Acknowledgments}

We are grateful to Bill Hurst, Ev Doman, Stan Tixier, Harold Heady, and Bill Laycock for sharing their experiences and insights about the Forest Service. Hopefully, we have captured a small part of the history that is such an intrinsic part of their memories and intellect.

Authors are Rangeland Scientist and Director, USDA Forest Service, Rocky Mountain Research Station, Fort Collins, CO 80526 (Mitchell and Patton-Mallory); and Professor, School of Natural Resources, University of Arizona, Tucson, AZ 85721 (Ffolliott).

\section{References and Other Reading}

[Note: Nearly all of these references were written or coauthored by Forest Service scientists.]

1. RobeRTS, P. H. 1963. Hoof prints on forest ranges: The early years of national forest range administration. San Antonio, TX: The Naylor Co.

2. Chapline, W. R. 1980. First 10 years of the Office of Grazing Studies. Rangelands 2:223-227.

3. Mitchell, J. E., And D. Rollins. 1991. The SRM honor awards program. Rangelands 13(1):5-8.

4. SAmpson, A. W. 1919. Plant succession in relation to range management. Washington, DC: US Department of Agriculture Bulletin 791.

5. Keck, W. M. 1972. Great Basin Station-sixty years of progress in range and watershed research. Ogden, UT: Intermountain Forest and Range Experiment Station. USDA Forest Service Research Paper INT-118.

6. SAMPSON, A. W. 1952. Range management principles and practices. New York, NY: John Wiley \& Sons.

7. CAmpBell, R. S. 1948. Milestones in range management. Journal of Range Management 1:4-8. 
8. Ellison, L. 1954. Subalpine vegetation of the Wasatch Plateau, Utah. Ecological Monographs 24:89-184.

9. ElLison, L. 1960. Influence of grazing on plant succession of rangelands. The Botanical Review 26:1-78.

10. Ellison, L., A. R. Croft, AND R. W. BAILEy. 1951. Indicators of condition and trend on high range-watersheds of the Intermountain Region. Washington, DC: US Department of Agriculture. Agriculture Handbook No. 19.

11. KNIGHT, R. L. 2002. The ecology of ranching, In: R. L. Knight, W. C. Gilgert, and E. Marston [eds.]. Ranching west of the 100th meridian. Covelo, CA: Island Press. p 123-144.

12. REYNOLDS, R. V. R. 1911. Grazing and floods: a study of conditions in the Manti National Forest, Utah. Forest Service Bulletin 91.

13. Plummer, A. P., D. R. Christensen, and S. B. Monsen. 1968. Restoring big game range in Utah. Salt Lake City: Utah State Department of Fish and Game. Publication 68-3.

14. Prevedel, D. A., E. D. McArthur, And C. M. Johnson. (in press). Beginnings of range management: an anthology of the Sampson-Ellison photo plots (1913 to 2003) and a short history of the Great Basin Experiment Station. Ogden, UT: Rocky Mountain Research Station. General Technical Report.

15. McArThur, E. D. 2001. The Shrub Sciences Laboratory at 25 years-Retrospective and prospective. In Shrubland ecosystem genetics and biodiversity: Proceedings. E. D. McArthur and D. J. Fairbanks [compilers]. Ogden, UT: Rocky Mountain Research Station. RMRS-P-21. p 3-41.

16. Seefeldt, S. S., And W. Laycock. The United States Sheep Experiment Station: shedding light on rangeland ecosystems and their management. Rangelands (in preparation).

17. Price, R. 1976. History of Forest Service research in the Central and Southern Rocky Mountain region-1908-1975. Fort Collins, CO: Rocky Mountain Forest and Range Experiment Station. General Technical Report RM-27.

18. SKOVLIn, J. M. 1991. Fifty years of research progress: A historical document on the Starkey Experimental Forest and Range. Portland, OR: Pacific Northwest Research Station. General Technical Report PNW-GTR-266.

19. Secretary of Agriculture. 1936. The western range. Washington, DC: US Government Printing Office. Senate Document 199.

20. Frasier, G. W., AND K. A. Holland. 2004. Rangeland hydrology research: lessons we have learned in forty years. In: G. G. Ice and J. D. Stednick [eds.]. A century of forest and wildland watershed lessons. Bethesda, MD: Society of American Foresters. p 263-275.

21. Stoddart, L. A., AND A. D. SMith. 1943. Range management. New York, NY: McGraw-Hill Book Co. [Note: The first range management textbooks, written by A.W. Sampson, were published in the 1930s $\{\mathrm{H}$. Heady, personal communication, March 30, 2005\}].

22. Hutchings, S. S., AND G. StewarT. 1953. Increasing forage yields and sheep production on Intermountain winter ranges. Washington, DC: US Department of Agriculture Circular 925. $63 \mathrm{p}$.
23. Hull, A. C., JR., And J. F. Pechanec. 1947. Cheatgrass-a challenge to range research. Journal of Forestry 45:555-564.

24. Stoddart, L. A., H. Clegg, B. S. Markham, and G. STEWART. 1951. The halogeton problem on Utah's ranges. Journal of Range Management 4:223-227.

25. Astroth, K. A., And N. C. Frischknecht. 1984. Managing intermountain rangelands: Research on the Benmore Experimental Range, 1940-1984. Ogden, UT: Intermountain Forest and Range Experiment Station. General Technical Report 175.

26. [AnOnYMous]. National Grasslands management-A primer. Available at: http://www.fs.fed.us/r2/nebraska/gpng/contents. html.

27. Joyce, L. A. 1989. An analysis of the range forage situation in the United States: 1989-2040. Fort Collins, CO: Rocky Mountain Forest and Range Experiment Station. General Technical Report RM-180.

28. Mitchell, J. E. 2000. Rangeland resource trends in the United States. Fort Collins, CO: Rocky Mountain Research Station. General Technical Report RMRS-GTR-68.

29. Forest History Society. 2002. US Forest Service history: Policy. Available at: http://www.lib.duke.edu/forest/Research/ usfscoll/policy/. The first wilderness area in the United States was created in 1924 on the Gila National Forest in southwestern New Mexico. This action resulted from the persuasions of Aldo Leopold, then an R-3 staff officer. In 1939, regulations written by Forest Service employee and celebrated wilderness supporter Bob Marshall were introduced to establish Wilderness and Wild Areas within the National Forest system. By 1963, the agency had stewardship over 14.5 million acres of Wilderness, Primitive, Wild, and Canoe Areas.

30. Stoddart, L. A., A. D. Smith, And T. W. Box. 1975. Range management. 3rd ed. New York, NY: McGraw-Hill Book Co.

31. Kessler, W. B., H. SalWasser, C. W. Cartwright, JR., AND J. A. CAPlan. 1992. New perspectives for sustainable natural resources management. Ecological Applications 2:221-225.

32. GRumbine, R. E. 1994. What is ecosystem management? Conservation Biology 8:27-38.

33. Mitchell, J. E., K. A. Maczko, L. A. Hidinger, And E. T. BARTLETT. Criteria and indicators of sustainable rangeland management: introduction. Rangeland Ecology and Management (in press).

34. USDA FoREST SERVICE. 2005. Strategic planning and resource assessment. Available at: http://www.fs.fed.us/plan/.

35. [ANONYMOUS]. Sustainable rangelands roundtable. Available at: http://sustainablerangelands.cnr.colostate.edu/.

36. Blaisdell, J. P., V. L. Duvall, R. W. Harris, R. D. Lloyd, AND E. H. REID. 1970. Range research to meet new challenges and goals. Journal of Range Management 23:227-234.

37. Hormay, A. L., AND A. B. EvanKo. 1958. Rest-rotation grazing- $\mathrm{a}$ new management system for perennial bunchgrass ranges. Berkeley: California Forest and Range Experiment Station. Miscellaneous Paper 27.

38. Williams, G. W. 2000. The USDA Forest Service- the first century. Washington, DC: USDA Forest Service. 